1972

\title{
Effect of Increasing Depth on Salinity in the James River Estuary
}

Maynard M. Nichols

Virginia Institute of Marine Science

Follow this and additional works at: https://scholarworks.wm.edu/vimsbooks

Part of the Oceanography Commons

\section{Recommended Citation}

Nichols, Maynard M., "Effect of Increasing Depth on Salinity in the James River Estuary" (1972). VIMS Books and Book Chapters. 17.

https://scholarworks.wm.edu/vimsbooks/17

This Book Chapter is brought to you for free and open access by the Virginia Institute of Marine Science at W\&M ScholarWorks. It has been accepted for inclusion in VIMS Books and Book Chapters by an authorized administrator of W\&M ScholarWorks. For more information, please contact scholarworks@wm.edu. 


\title{
Effect of Increasing Depth on Salinity in the James River Estuary
}

\author{
MAYNARD M. NICHOLS \\ Virginia Institute of Marine Science \\ University of Virginia \\ Gloucester Point, Virginia 23062
}

\begin{abstract}
The effects of channel deepening on the salinity and density flow in the James River estuary, Virginia, were studied to predict changes that might affect oyster production. A hydraulic model with $1: 1,000$ horizontal and 1:100 vertical scales was employed to integrate three-dimensional changes in salinity and velocity through reaches of variable bottom geometry. After natural characteristics of the tide, current, and salinity were reproduced in the model, tests were run at three levels of steady river inflow, before and after a 3-meter channel deepening. Results were combined with corollary field observations to evaluate changes in present-day ecological conditions.

Deepening produced the greatest salinity change in the middle estuary where the major cut was performed. The lower water layer located mainly in the channel became saltier by about 0.5 part per thousand, whereas the upper layer over the oyster shoals became fresher by about 0.2 part per thousand. Changes in bottom water salinity were greatest at intermediate inflow and least at very low inflow. High fresh-water inflow created the greatest change in vertical salinity gradient. With greater stratification, tidal velocities were less effective in promoting vertical mixing between lower and upper estuarine water layers, and the net volume transport in each layer was reduced.

Since the changes in salinity and flow pattern due to channel deepening were small, no effects inimical to the oyster fishery were predicted. Similarly the prospective changes in sedimentary regime will not offset the beneficial effects of the proposed deepening project.
\end{abstract}

\section{CONTENTS}

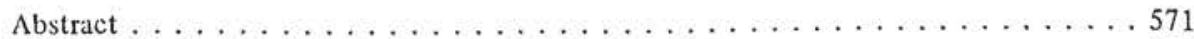

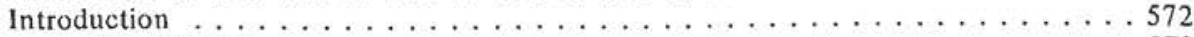

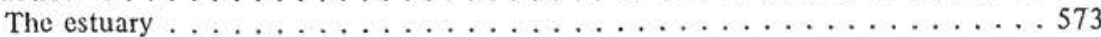


Model construction and instrumentation . . . . . . . . . . . . . . 575

Field measurements . . . . . . . . . . . . . . . . . . 577

Verification and operating characteristics $\ldots \ldots \ldots \ldots \ldots \ldots \ldots \ldots$

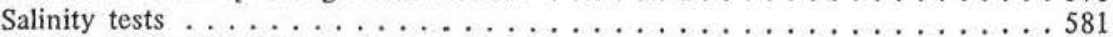

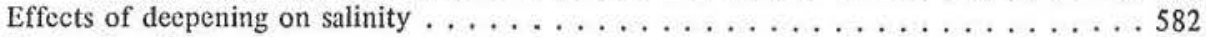

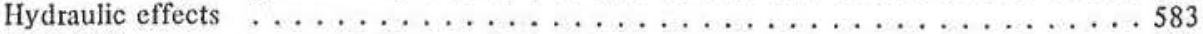

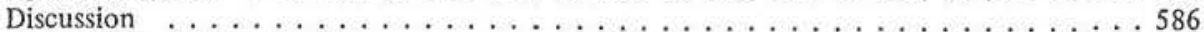

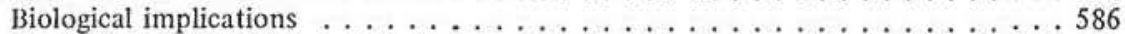

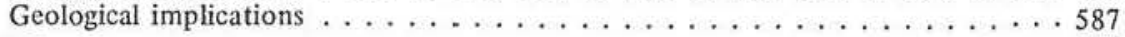

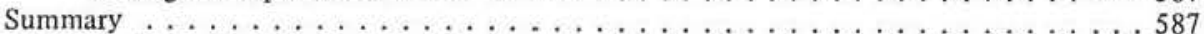

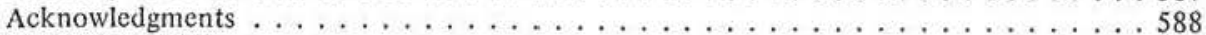

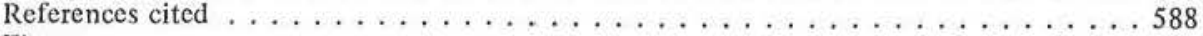

Figure

1. James River estuary showing general location, model limits, location of stations, hydrographic gages, points of fresh-water inflow, and course of the shipping

channel . . . . . . . . . . . . . . . . . . . . . . 574

2. Model bed during construction showing different stages of molding . . . . . 575

3. Longitudinal profile along the course of the present shipping channel . . . . . 576

4. View of model looking upstream from Hampton Roads showing salinity withdrawal apparatus on frames athwart the estuary $\ldots \ldots \ldots \ldots \ldots 77$

5. Comparison of tidal range in the model and in the prototype, from Hampton Roads to Richmond, August $16-17,1964 \ldots \ldots \ldots \ldots$. . . . . . 578

6. Time-velocity curve in the prototype at Station 2, depth 8 meters, September 11,1964 , and the corresponding curve in the model, verification test number 1 . 579

7. Comparison of salinity variations in the model sump and corresponding variations at Thimble Shoals for verification test number 2 through an annual cycle . . 579

8. Distribution of mean differences between the prototype and model salinity in surface water and in bottom water attained by verification . . . . . . . 580

9. Comparison of model and prototype salinities with time at Station 65 , "Miles," through a range of inflows representing flows in $1964 \ldots \ldots \ldots \ldots \ldots 1$

10. Profile of James River estuary and differences of salinity due to deepening the 35 -foot $(10.7$ meter $)$ channel . . . . . . . . . . . . . . . . 584

11. Distribution of bottom isohalines in the model before and after channel Table deepening, at 89.6 cubic meters per second steady inflow at Richmond . . . 585

1. Model scales . . . . . . . . . . . . . . . . . . . . . . 576

2. Average salinity values, parts per thousand, in the model at Thimble Shoals for different tests and corresponding differences in salinity between tests . . . . 583

\section{INTRODUCTION}

Like many estuaries leading inland to cities on the mid-Atlantic coast, the James River estuary lacks sufficient natural water depth to accommodate modern ocean-going ships. A depth increase of 3 meters for 140 kilometers is required to allow deep-draft ships to reach the inland city of Richmond, Virginia. The proposed channel would cut through an economically important oyster seedproducing area, renowned as one of the best in the world. It was feared that a lowering of the channel floor might produce a permanent change in the salinity and circulation and thus impair successful production of oysters. It became essential to know in advance what physical changes channel deepening would produce; then, potential biological consequences could be evaluated.

To predict the effects of channel deepening, a scale hydraulic model of the entire James River estuary was constructed. In the model, selected hydrographic conditions critical to oyster ecology were established; velocity and salinity were measured, first with the existing channel, then with the deepened channel. Differences in the measurements made before and after deepening were assumed 
to represent changes related to the effect of increased channel depth. When the distributions of these changes were delineated in vertical and horizontal sections, they showed areas where the effects of deepening would be greatest in the natural estuary or prototype. The most important changes studied were (1) changes in the magnitude and distribution of salinity, and (2) changes in the net velocity and volume transport. This paper describes characteristics of the model and shows the effects of channel deepening on the density flow and salinity distribution.

Although the James River model was initially built to study ecological conditions, construction and operation were essentially the same as used for engineering studies. For example, the James model was built and run like fixed-bed models of the Delaware and Hudson rivers and Narragansett Bay as described by Simmons (1966). Unlike other estuaries that empty into the ocean, the James drains into Lower Chesapeake Bay where salinity varies both tidally and seasonally. As a result of early studies (Stroup and Lynn, 1963; Whaley and Hopkins, 1952), a great wealth of prototype data has accumulated. A theory of estuarine flow was developed and tested in the James by Pritchard (1952b, 1955). This background of knowledge permitted a closer evaluation of model results, as well as a more comprehensive integration of model and prototype data, than was possible in studies of other east coast estuaries.

Construction, verification, and testing of the model were carried out by engineers of the Waterways Experiment Station at Vicksburg, Mississippi, from September 1964 to September 1966. Field data were collected by scientists of the Virginia Institute of Marine Science in the summer of 1964. This effort was part of a series of studies to investigate the physical and biological characteristics of the James. The investigation was sponsored by the Commonwealth of Virginia and conducted by the Virginia Institute of Marine Science.

\section{The Estuary}

From the head of tidal reaches at Richmond, the James River flows 145 kilometers across a coastal plain before emptying into Chesapeake Bay (Fig. 1, inset). Along its course four large tributaries lead into the estuary: the Appomattox, Chickahominy, Nansemond, and Elizabeth rivers (Fig. 1). The waterway passes two industrial areas, Hopewell and the Newport News-Norfolk area known as Hampton Roads. At Hopewell the river is a source of domestic and industrial water as well as an avenue for waste disposal. At Hampton Roads the estuary serves overseas shipping facilities which handle large exports of coal. Future development of industry along the estuary course may depend on improving the waterway as an avenue of commerce.

The James River is narrowly funnel-shaped and relatively shallow, averaging 3.7 meters deep at mean low water. Sediment is partially filling the estuary at different rates through a broad range of salinity and bottom topography. Deposition is highest in the middle estuary, particularly in Burwell Bay where rates are greater than 2 meters per 70 years, and farther seaward along the south channel shoulder (Nichols, this volume, Fig. 14). The main channel is relatively free of deposition and requires maintenance dredging only in limited reaches above the estuary head.

Extensive shoals have formed between the central channel and the shoreline in water depths less than 4 meters. Most of the shoals consist of mud but some occur as natural oyster bars. The bars extend upstream as far as the seaward limit 


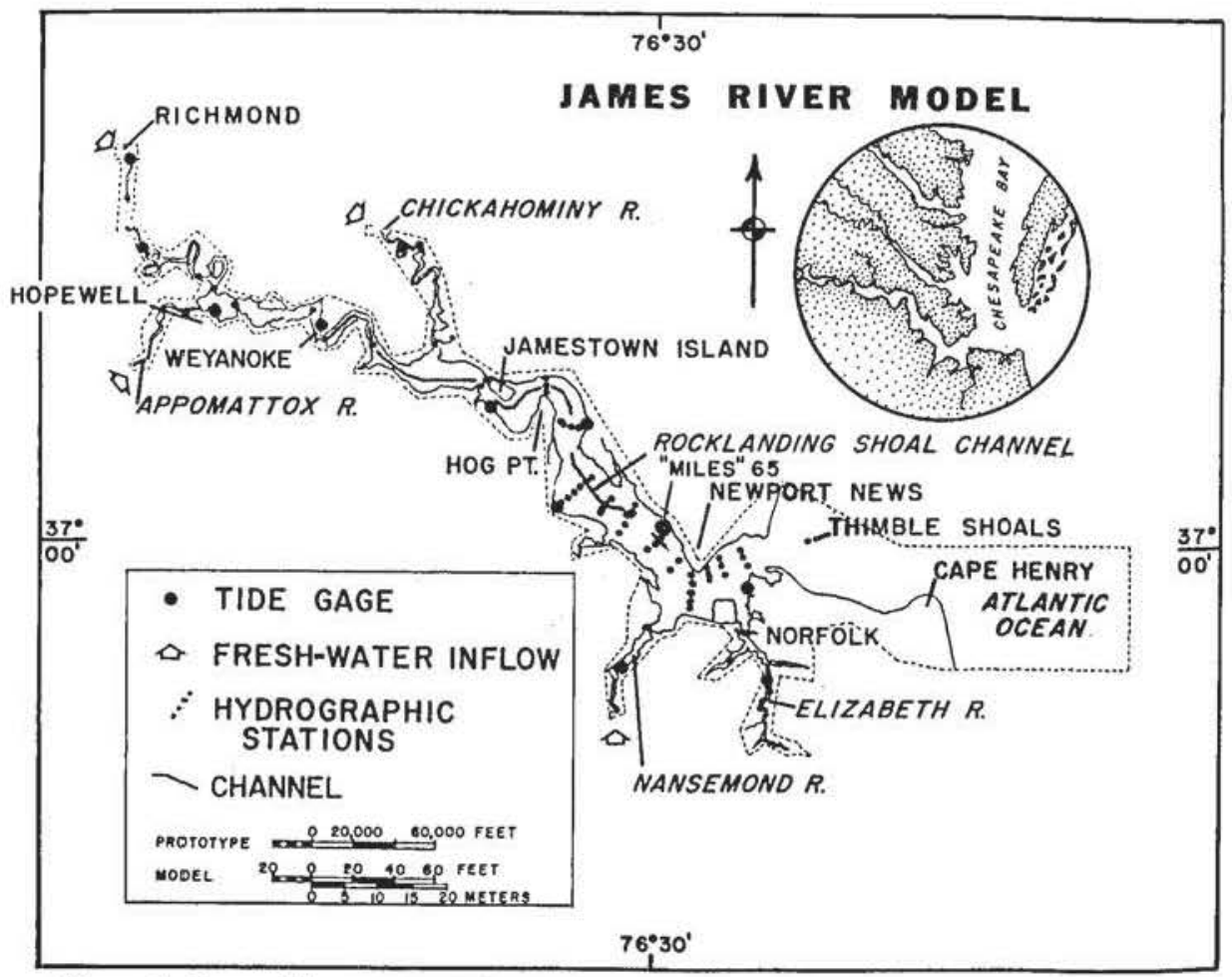

Figure 1. James River estuary showing general location (inset), model limits, location of stations, hydrographic gages, points of fresh-water inflow, and course of the shipping channel through the saline reaches.

of fresh water in times of flood, a limit located just below Hog Point (Fig. 1), whereas they extend downstream to Hampton Roads. Farther seaward in water saltier than about 10 to 15 parts per thousand, the oysters are generally overcome by predators and disease. Thus, the distribution of the oyster bars is more or less fixed by the distribution of salinity.

Salinity of estuarine water varies both with time and with distance away from the river entrance. It ranges from nearly 0 part per thousand at the head to an average of 24 parts per thousand at the mouth. The seaward increase is greatest in the middle estuary, the "gradient zone" (Rochford, 1951). In this zone, haline stratification is most pronounced and salinity fluctuates more than 7 parts per thousand during a tidal cycle. In spring, high fresh-water inflow limits the upstream extent of salty water to 38 kilometers above the mouth. When river inflow is diminished in summer and fall, salty water penetrates upstream almost to Weyanoke, 98 kilometers above the mouth. With this marked seasonal change, vertical structure of estuarine water alternates from moderately stratified to well mixed, that is, from type B to type C of Pritchard (1955).

The chief movement of water in the estuary is produced by the tide. Mean range in the estuary proper is 70 centimeters, and currents locally reach 80 centimeters per second. When river inflow is relatively high, the ratio of discharge to mean tidal prism is close to 0.10 , whereas during low inflow the ratio is about 0.03. An account of the important physical features of the James and the theory of estuarine flow is given by Pritchard (1952b). 


\section{MODEL CONSTRUCTION AND INSTRUMENTATION}

The model was built inside a hangarlike shelter on a 1-hectare site at the Waterways Experiment Station, Vicksburg, Mississippi. The bed was molded in concrete (Fig. 2) to a horizontal scale of $1: 1,000$ and a vertical scale of $1: 100$. The tenfold vertical scale distortion is unavoidable; however, river inflow, tidal currents, and time are interrelated inasmuch as they are scaled according to Froudian scale relations (Simmons, 1959). At these geometric scales, the salinity scale is conveniently $1: 1$. Table 1 summarizes the model scales. Bottom geometry of the model was made to conform to the bathymetry delineated on recent "boat" sheets of the U.S. Coast and Geodetic Survey dated 1945-1952; the floor of the shipping channel was based on bottom topography surveyed by the U.S. Army District Engineers, 1956. To discover if any large depth changes had occurred since these surveys, the estuary was resurveyed in 1964 on nine selected cross transects, the same as those used for hydrographic observations. The model reproduced approximately 2,340 square kilometers of the estuary, including tidal reaches of major tributaries, plus a portion of Lower Chesapeake Bay and its entrance reaches in the Atlantic Ocean, and extended 27.2 kilometers offshore (Fig. 1).

The proposed shipping channel was built in sections to facilitate later alterations. The channel would cut segments of the natural channel along a 140-

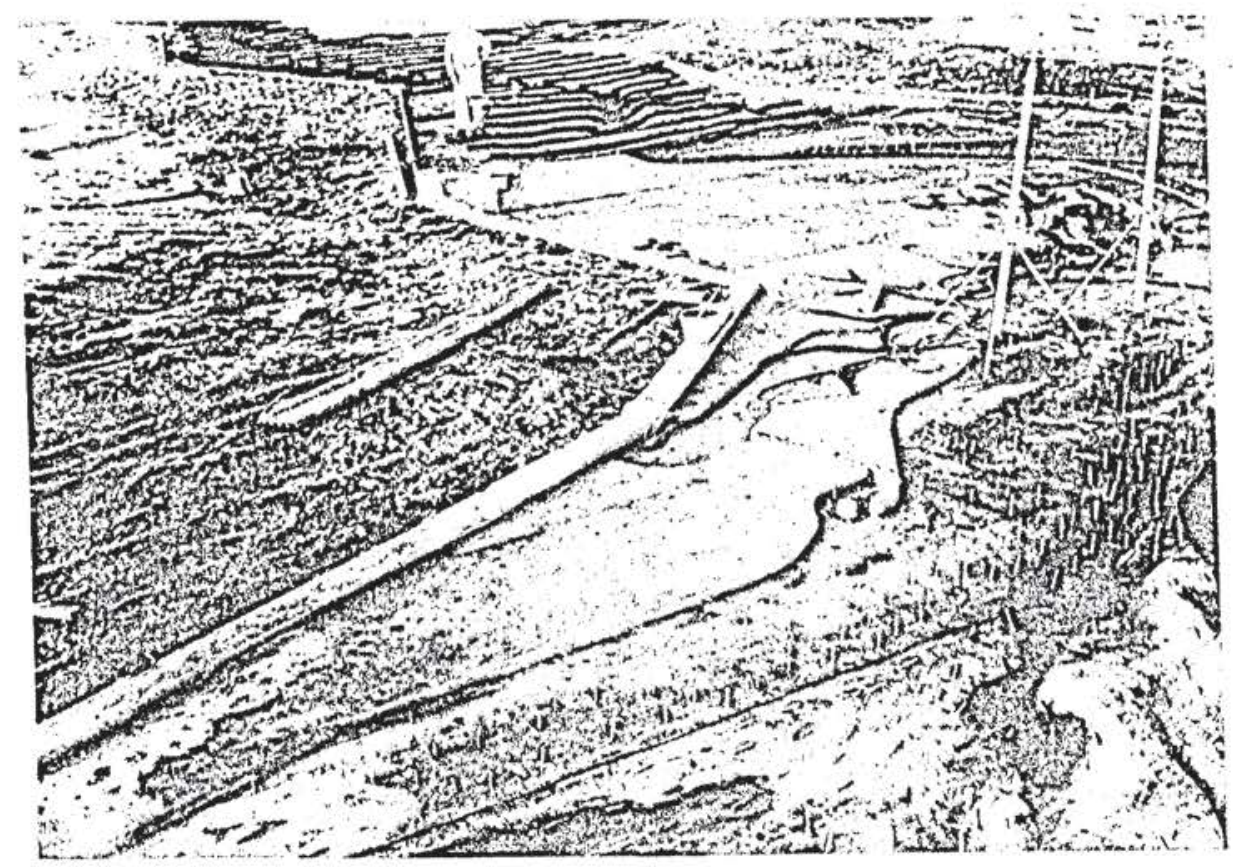

Figure 2. Model bed during construction showing different stages of molding. Metal resistance tabs protrude from the bed in the foreground. (Photo by Waterways Experiment Station, Vicksburg, Mississippi.) 
kilometer (prototype) course at a controlling depth of 10.7 meters and a width of 91.4 meters. Figure 3 shows how the proposed channel would "smooth out" the naturally rough channel profile by lowering segments of the channel floor. In the saline reaches, one of the major cuts ( 16 kilometers) would run through the main oyster-producing reach near Rocklanding Shoal (Fig. 1 and Fig. 3). Another channel-deepening that was tested in the model, though not fully reported herein, called for a 3-meter deepening (from 10.7 meters to 13.7 meters) for a distance of 6.4 kilometers seaward from Newport News (U.S. Congress, 1965). (For all tests reported herein, except for tests 1A, 2A, and 3A referred to in Table 2, the Newport News Channel through Hampton Roads was established at a depth of 13.7 meters.) These changes of the channel floor are part of a series of alterations, now here, then there, that have proceeded with development of the estuary over the years. Although each improvement has been relatively small and without appreciable effect, the cumulative effect, if additive, may be great.

Fresh water was introduced into the model through the James River at Richmond and through each of the primary tributaries, the Appomattox, Chickahominy, and Nansemond. The combined discharge of the minor tributaries, the Elizabeth, Pagan, and Warwick, was introduced at the head of the Nansemond (Fig. 1). Inflow was controlled manually and rates of inflow were measured by either a flowmeter or a Van Leer weir. Source "sea" water with a relatively constant salinity of 24.2 parts per thousand was prepared in a rectangular sump, 12.2 meters x 14.6 meters and 2.1 meters deep, by introducing sodium chloride in the form of rock salt. When fed to the estuary, the salty water was mixed with freshened water near the Chesapeake Bay entrance, so that water flowing in the mouth of the James had a salinity close to that in the prototype.

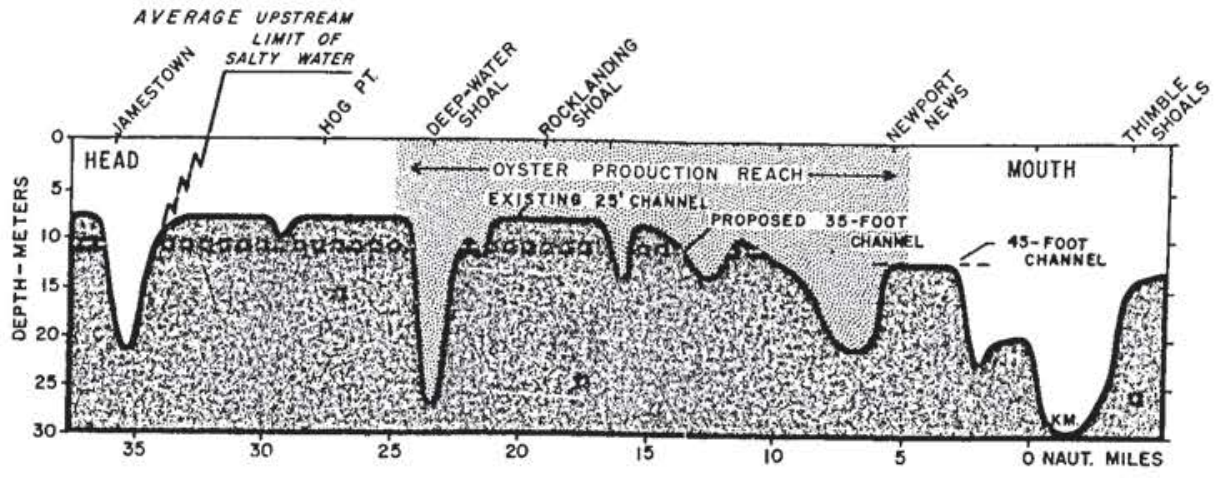

Figure 3. Longitudinal profile along the course of the present shipping channel at the 25 -foot $(7.7 \mathrm{~m})$ depth in relation to the proposed 35 foot $(10.7 \mathrm{~m})$ deepening and 45 -foot $(10.7 \mathrm{~m})$ deepening near Newport News, oyster production reach, and the average upstream limit of salty water. 
The rise and fall of the tide was produced by alternately pumping water into the model and draining by gravity flow; the action was regulated by an automatic, electrically controlled valve in the outflow line. Tidal amplitude and corresponding tidal times were reproduced continuously to scale at the control station, Sewells Point, Hampton Roads. Farther upstream, tidal heights were measured intermittently on stationary point gages at 11 stations. Current velocities were measured manually with miniature Price rotating cup meters.

At periodic intervals water samples were drawn by vacuum through small intakes set in the model at 2- to 3-centimeter depth intervals and collected in vials. Samples were obtained simultaneously at all depths and at a series of stations in each cross section. Inasmuch as the rate of water withdrawal was usually faster than the flow of water past the intake, the sample water probably contained an admixture of water from above and below the intake depth. Salinity of water samples was determined by titration with silver nitrate using potassium chromate as an indicator following the Mohr method. Figure 4 shows a general view of salinity sampling apparatus in the model.

\section{Field Measurements}

In order to supply data required to reproduce hydraulic characteristics in the model, an extensive hydrographic survey was carried out in the estuary between May and October 1964, a time of relatively low and steady river inflow in the range 25 to 47 cubic meters per second at Richmond. Sixty-four anchor stations were occupied, including stations on transects across the estuary and along the channel course (Fig. 1). On each transect, simultaneous observations were made

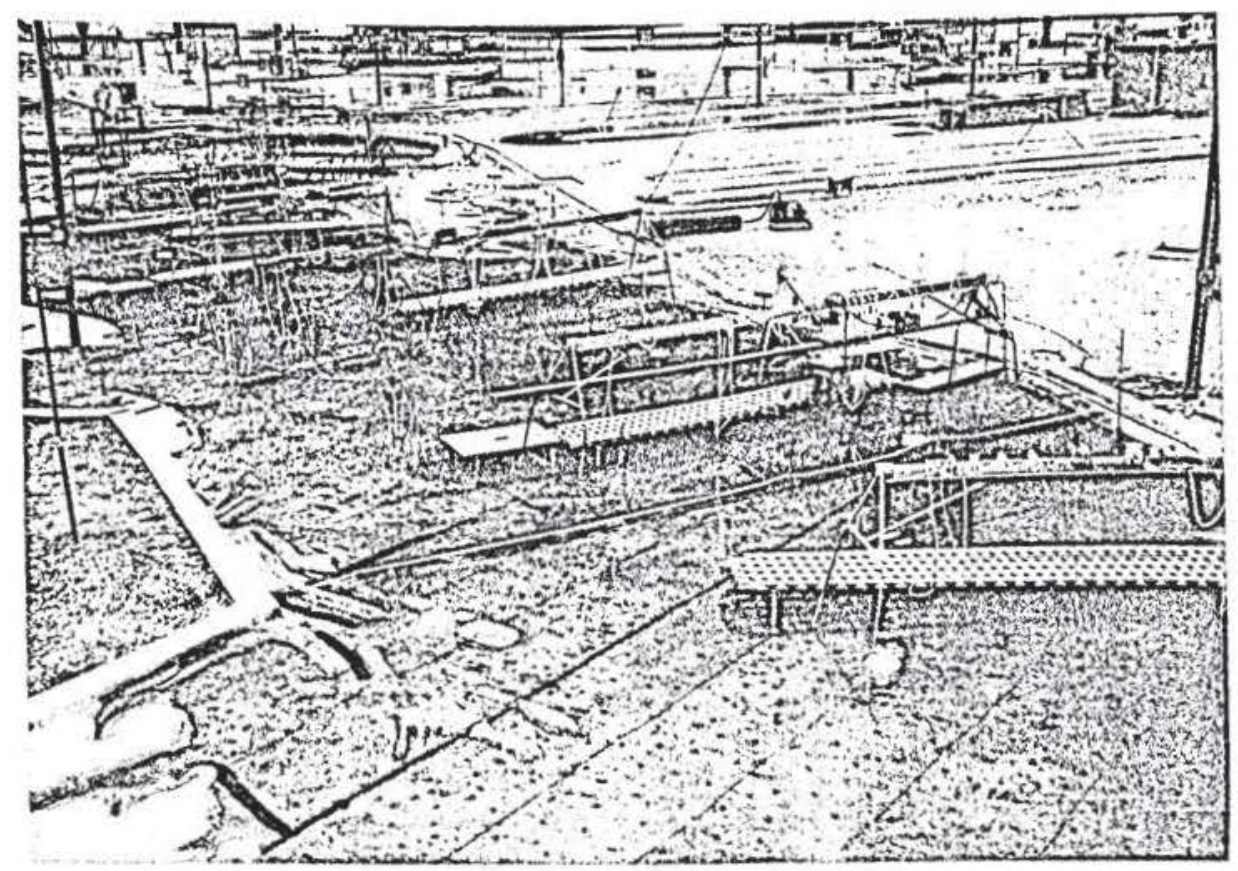

Figure 4. View of model looking upstream from Hampton Roads, showing salinity withdrawal apparatus on frames athwart the estuary. (Photo by Waterways Experiment Station.) 
during mean stage of tide when wind speeds were generally less than 6 meters per second. At each station observations of current speed and direction, salinity, and temperature were made every 30 minutes, at 2- to 3-meter depth intervals throughout one tidal cycle. During the observation period, measurements of tidal amplitude were recorded concurrently on 12 tide gages. River discharge was recorded daily at Richmond and near the head of each tributary (Fig. 1). Salinity was monitored on a conductivity meter installed at one station ("Miles," number 65 ) in the middle estuary. Most measurements of current velocity were made with a Savonius rotor and vane; salinity of water samples returned to the laboratory was determined on an Industrial Instruments conductivity unit RS-7a. Procedural details and prototype data are given in Shidler and MacIntyre (1967).

\section{Verification and Operating Characteristics}

Before testing the effects of channel deepening, the hydraulic behavior and the salinity characteristics of the model were made to correspond to those in the prototype at the proper inflow and time scales.

First, the model was made to duplicate the natural propagation of the tide by successive adjustments of the resistance strips. The agreement of the tidal ranges was within 5 centimeters at all stations, as illustrated in Figure 5. Tidal elevations, that is, high and low water, based on mean low water at the Hampton Roads tide station, were made to agree to within 0.15 centimeter for stations downstream of Hog Point and within 0.3 centimeter upstream from this point. It is supposed that these departures in tidal elevations were due to a difference between the Hampton Roads data and the local bench mark elevations to which the tide staves were referred in the prototype. The tidal similitude was deemed adequate inasmuch as the model reproduced the main features of the tide, particularly the tidal range.

Current velocities were then measured at each station and resistance strips were readjusted to make the flow agree with that in the prototype. A comparison of predominant flows after final adjustment, calculated by the method of Simmons (1955), showed that differences averaged less than plus or minus 10 percent throughout the estuary. Reproduction of representative prototype and model time-velocity curves is shown in Figure 6 for Station 2, Hampton Roads.

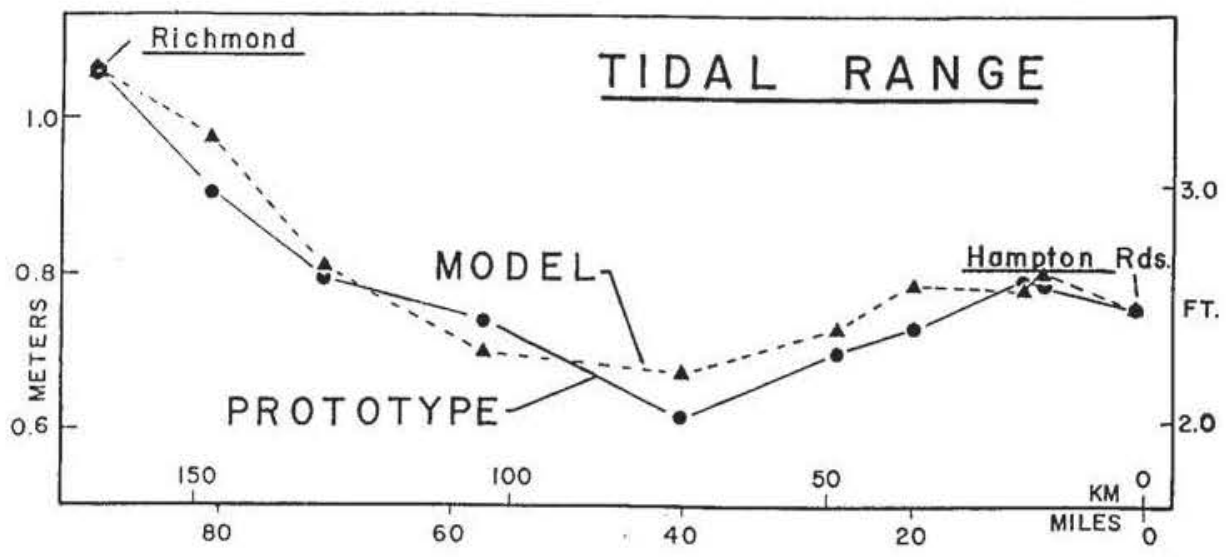

Figure 5. Comparison of tidal range in the model (test 6) and in the prototype, from Hampton Roads to Richmond, August 16-17, 1964. 


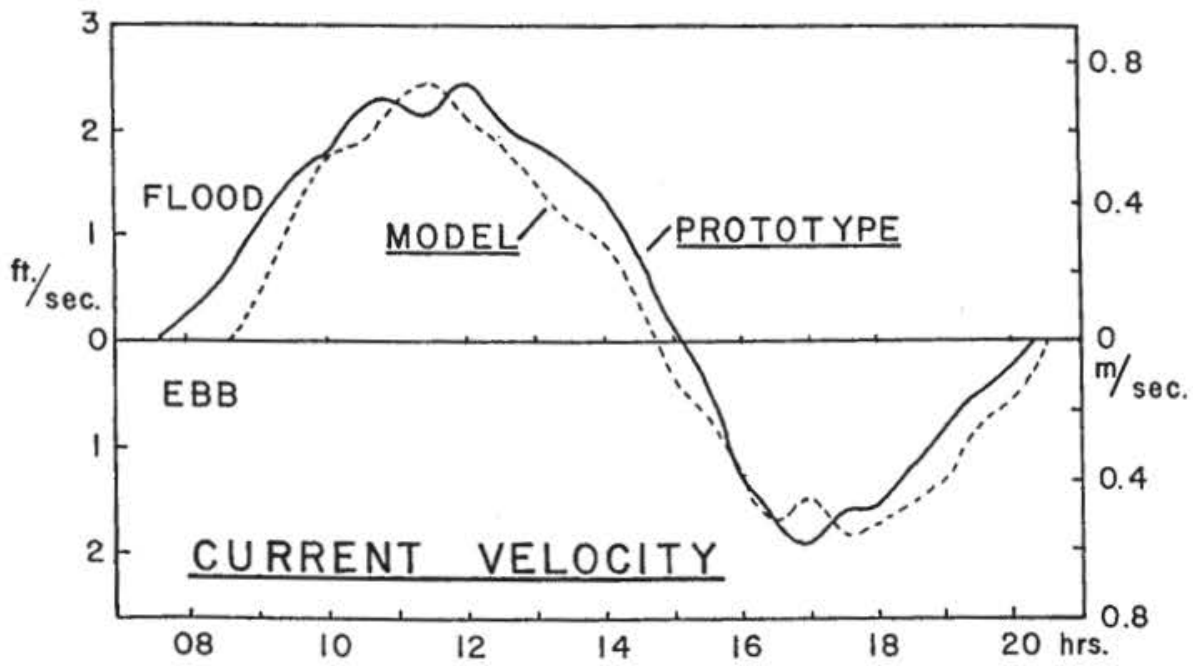

Figure 6. Time-velocity curve in the prototype at Station 2, depth $8 \mathrm{~m}$, September 11 , 1964 , and the corresponding curve in the model, verification test number 1 .

Inasmuch as the model was constructed for the main purpose of predicting salinity changes, it was important to accurately reproduce all characteristics of salinity. Both the horizontal and the vertical distribution of salinity throughout the estuary, as well as the temporal variation at a single station, were reproduced in the model under controlled conditions of river inflow, source salinity, and. tide.

In contrast to many estuaries that empty into the ocean with a nearly constant salinity of about 34 parts per thousand, the James drains into Lower Chesapeake Bay, which varies in salinity annually from about 21 parts per thousand to 26 parts per thousand. Sump salinities were varied by "cut and trial" until salinity of water flowing into the mouth of the James along the bottom was close to that measured at the corresponding location in the prototype. Figure 7 shows the variations of sump salinity, which were pro-

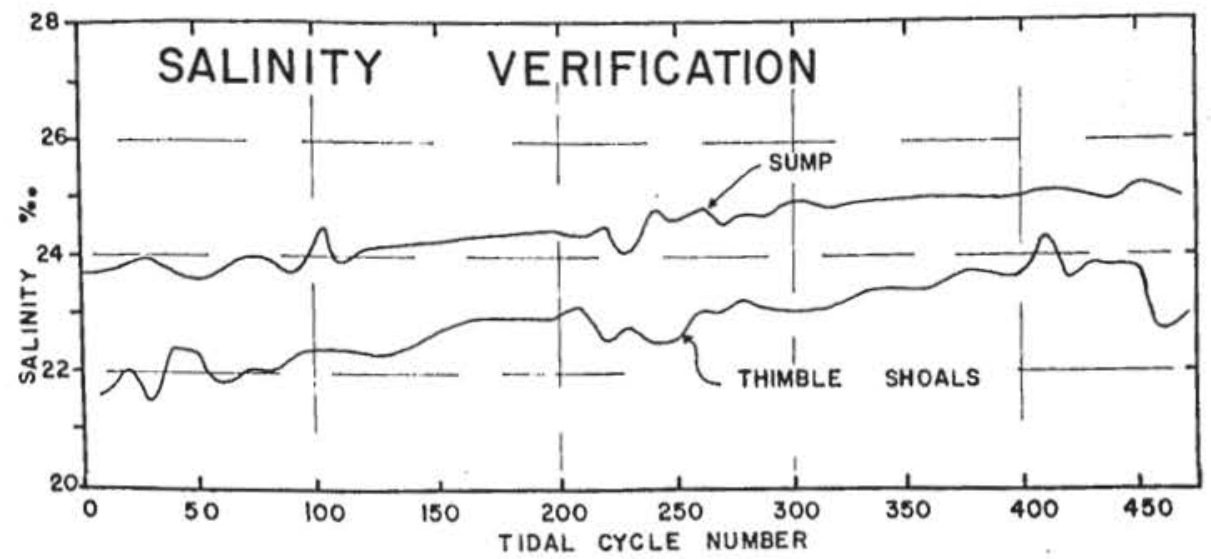

Figure 7. Comparison of salinity variations in the model sump and corresponding variations at Thimble Shoals for verification test number 2 through an annual cycle; salinity sampled at low slack water on the surface. Salinity in parts per thousand $(\%)$. 
grammed to increase linearly from 23.7 parts per thousand to 25.0 parts per thousand, in relation to salinity at Thimble Shoals, a station off the James mouth. In the run, salinity intermittently fluctuated by \pm 0.5 part per thousand from the programmed values, suggesting the limits of accuracy attained in control of salinity in the sump or in analyzing the salt concentrations. Corresponding salinities at Thimble Shoals over the period as a whole generally followed those of the sump with small fluctuations varying \pm 0.6 part per thousand from average programmed values.

Results of salinity verification (Fig. 8) show that mean differences derived by averaging 13 instantaneous values obtained over tidal cycle, lie between +0.9 part per thousand and -1.8 parts per thousand over most of the estuary, except near Newport News Point and in the upper reaches above Hog Point. Here values reached +2.5 parts per thousand, that is, the model is 2.5 parts per thousand saltier than the prototype. Relatively large differences $(>2.0$ parts per thousand) in the freshened upper estuary are attributed to the fact that there is an unknown contribution of fresh water in the prototype, including ground water and inflow from minor lateral tributaries. When river inflow is low,

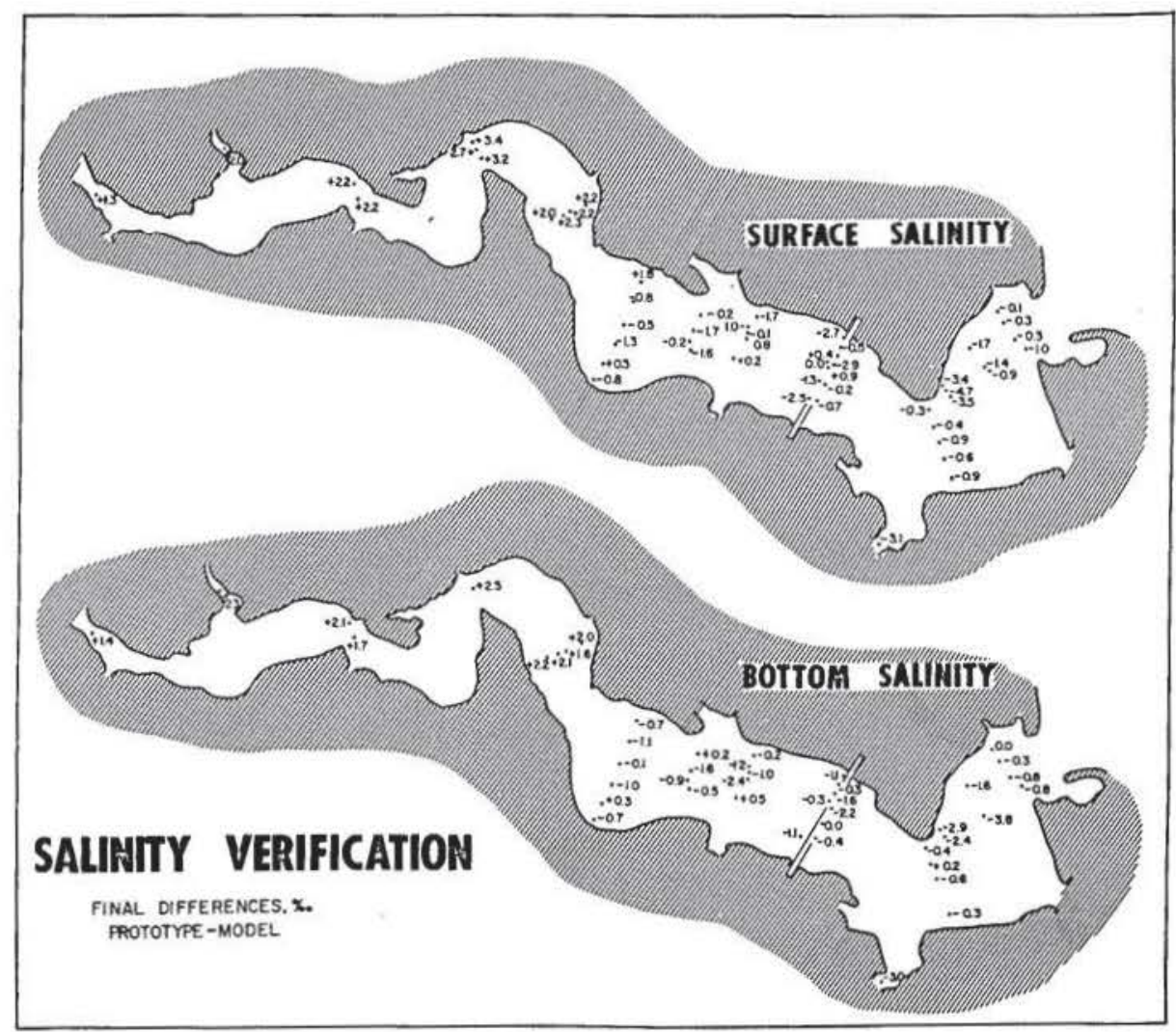

Figure 8. Distribution of mean differences between the prototype and model salinity in surface water (upper) and in bottom water (lower) attained by verification. A + sign indicates the model is slightly saltier than the prototype; a - sign indicates the model is fresher than the prototype. Salinity in parts per thousand $(\% \circ)$. 
these contributions become relatively important; consequently, the percentage error is quite large, more than 50 percent of the salinity range.

The temporal distribution of salinity at one middle estuarine station ("Miles," number 65, Fig. 1) was verified in the model through a range of inflow for a 9-month period, April through December 1964 (530 cycles). The results for this year of low inflow are shown in Figure 9. Salinity in the prototype, observed once daily at high and low slack water during the period, exhibited small fluctuations with a period of about two weeks, reflecting spring and neap variations in the tidal range. Corresponding model values, measured at mean tide, fall within the range of the prototype values most of the time, indicating statisfactory agreement with the prototype.

Final verification tests showed that salinity in the model was similar to that in the prototype with time, and from place to place, for low to moderate conditions of river inflow and for comparable conditions of the tide and source salinity. The satisfactory salinity reproduction suggests that tidal and local current reproduction is also satisfactory, and it may be assumed that tidegenerated horizontal-mixing forces in the model were similar to those in the natural estuary. These hydraulic elements are essential to establishing the correct internal density circulation.

\section{Salinity Tests}

Tests were designed to observe differences in salinity throughout the estuary before and after channel deepening. Three sustained fresh-water inflows were run, $28,89.6,322$ cubic meters per second at Richmond, plus proportionate inflows in each of the primary tributaries. The 322 cubic meters per second flow represented an average of monthly Richmond discharges for the months of January through April over a period of 57 years; similarly, 89.6 cubic meters per second is close to a mean of the lowest flows in each year for all years on record. The rationale for selecting these flows was that the long-term control of oyster predation and disease is most closely related to the average salinity in spring, especially high flows that occur in "wet years," in addition to occasional extreme salinities in late summer.

TIDAL CYCLE NUMBER

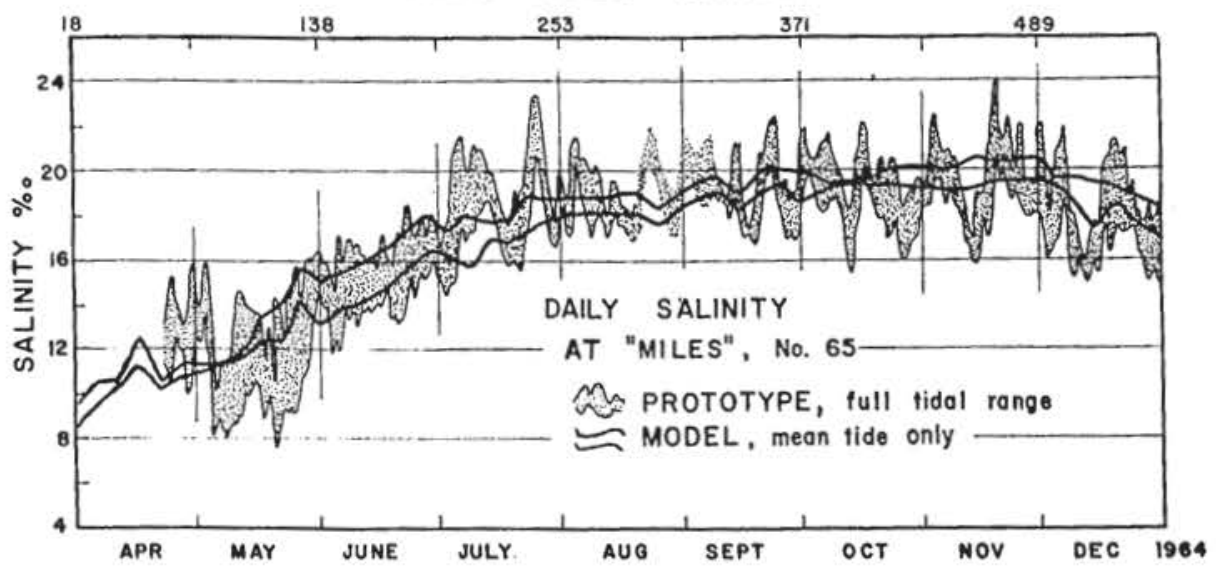

Figure 9. Comparison of model and prototype salinities with time at Station 65, "Miles," through a range of inflows representing flows in 1964. Salinity in parts per thousand ( $\% 0)$. 
Before water samples were collected for each test, the model was run for many tidal cycles at mean tide until the salinity regimen was close to or at steady state. The operation time that elapsed prior to salinity stability varied inversely with fresh-water inflow, the range at Richmond being from 42 cycles at 322 cubic meters per second, to 75 cycles at 84.6 cubic meters per second, to 182 cycles at 28 cubic meters per second. Stability was indicated by replication of time-salinity curves on a recording conductivity unit situated at the estuary head in the salinity zone of about 1 to 5 parts per thousand. Test samples were collected for analysis every 36 seconds (one prototype hour) over a tidal cycle and at 1.8- to 3.7-centimeter depth increments throughout the saline reaches.

The sump was programmed to produce a constant salinity of 24.2 parts per thousand for all levels of fresh-water inflow tested. Records of the salinities actually maintained in the sump during model operation are not available; however, inasmuch as salinity at Thimble Shoals off the James mouth varies directly with the sump salinity (Fig. 7), values at Thimble Shoals may be used as an index to compare the salinity of source water from test to test. Table 2 summarizes the time-averaged salinity at Thimble Shoals for each test. It is evident that salinity of inflowing source water varied within the range -0.9 to +1.3 parts per thousand from test to test, and under stratified conditions (tests 1 and $1 \mathrm{~A}$ ) differences varied +1.0 to 0.0 part per thousand from surface to bottom. These departures were believed to affect the salinity differences farther upstream with diminishing influence toward the head; therefore, the difference values were adjusted by assigning a small percentage correction (based on differences at Thimble Shoals values) to each station. Most corrections provided a reasonable "fit" except in the Hampton Roads area.

\section{EFFECTS OF DEEPENING ON SALINITY}

The model tests indicate that the 3-meter channel deepening would have a slight effect on the salinity regime. Although changes in the magnitude of average salinity were small, generally less than 1 part per thousand, the patterns of salinity shifted in a fashion that reflected the dynamic behavior of a two-layered estuarine system.

At high inflow (322 cubic meters per second at Richmond) when the estuary was partly mixed, near-surface water became fresher after deepening chiefly in the channel of the middle estuary, whereas near-bottom water in the channel, below about 5.5 meters depth, became saltier (Fig. 10A). Salinity increased most in the area near Rocklanding Shoal, where the major channel enlargement was performed. Channel deepening also produced a change in the salinity patterns at 89.6-cubic-meters-per-second Richmond inflow (tests 2 and 5, Fig. 10B), but in the channel the change was less marked than at high inflow. Salinity increased up to 1.0 part per thousand at the head of the Rocklanding Shoal channel, and the 10-parts-per-thousand isohaline penetrated upstream about 2.4 kilometers farther along the channel floor (Fig. 11). Over adjacent shoals, freshening locally reached 1.2 part per thousand and the 10-parts-per-thousand isohaline was displaced downstream almost 1.6 kilometers. Farther headward, where bottom salinities are less than 6 parts per thousand, the salinity change was very small, less than 0.3 part per thousand over most of the area, except for one station. Near the mouth, 
TABLE 2. AVERAGE SALINITY VALUES, PARTS PER THOUSAND, IN THE MODEL AT THIMBLE SHOALS FOR DIFFERENT TESTS AND CORRESPONDING DIFFERENCES IN SALINITY BETWEEN TESTS

\begin{tabular}{cccccc}
\hline \hline $\begin{array}{c}\text { Inflow, } \mathrm{m}^{3} / \mathrm{sec} \\
\text { Richmond }\end{array}$ & $\begin{array}{c}\text { Test } \\
\text { number }\end{array}$ & $\begin{array}{c}\text { Surface } \\
\text { salinity }\end{array}$ & $\begin{array}{c}\text { Salinity } \\
\text { difference }\end{array}$ & $\begin{array}{c}\text { Bottom } \\
\text { salinity }\end{array}$ & $\begin{array}{c}\text { Salinity } \\
\text { difference }\end{array}$ \\
\hline & $1 \mathrm{~A}$ & 17.7 & +1.0 & 23.9 & 0.0 \\
322 & 1 & 18.7 & -0.4 & 23.9 & -0.3 \\
322 & 4 & 18.3 & 23.9 & 0.0 \\
\hline 89.6 & $2 \mathrm{~A}$ & 20.9 & -0.4 & 24.0 & +0.1 \\
89.6 & 2 & 20.5 & +0.5 & 24.0 & -0.9 \\
89.6 & 5 & 21.0 & & 24.1 & +1.3 \\
\hline 28 & $3 \mathrm{~A}$ & 22.6 & -0.8 & 24.1 & 23.2 \\
\hline 28 & 3 & 21.8 & +1.2 & 24.5 & \\
\hline
\end{tabular}

Note: In tests 1,2 , and 3 , the channel depth was established for existing conditions; in tests 1A, 2A, and $3 \mathrm{~A}$ the Newport News channel was established 3 meters deeper than existing conditions; in tests 4,5 , and 6 , the James River channel was established 3 meters deeper than existing conditions.

salinity below mid-depth increased about 0.5 part per thousand over a broad area of Hampton Roads. This change may be attributed to a high sump salinity (see Table 2, compare tests 2 and 5) which persisted after the percentage corrections were applied (as explained earlier, see "salinity tests"). The effect of this apparent intrusion on salinity in upper reaches is uncertain.

At the very low inflow, 28 cubic meters per second at Richmond, when the estuary was relatively well mixed, changes in salinity were small, less than 0.5 part per thousand throughout most of the estuary, even when the combined effect of both Newport News and James channels was tested (Fig. 10C). Deepening of these channels moved the 15 parts-per-thousand isohaline upstream in the Rocklanding Shoal area only 1.6 kilometers in the channel and on the shoals.

\section{HYDRAULIC EFFECTS}

The effects of channel deepening on net water movement were studied by examination of (1) changes in the net nontidal velocity and flow predominance, and (2) changes in the net volume rate of flow through selected cross sections.

The vertical distributions of net velocity throughout the estuary displayed the typical two-way estuarine flow. Near-surface water was generally directed downstream mainly along the south (left) side, and movement in the lower layer was directed upstream, chiefly in the channel and along the north side (right side, viewed headward). When the distributions of net velocity together with flow predominance were studied closely in different reaches, considerable variation was evident both within a single cross section and from one reach to another. Many of these variations may be due to the varied geometry of the estuary 

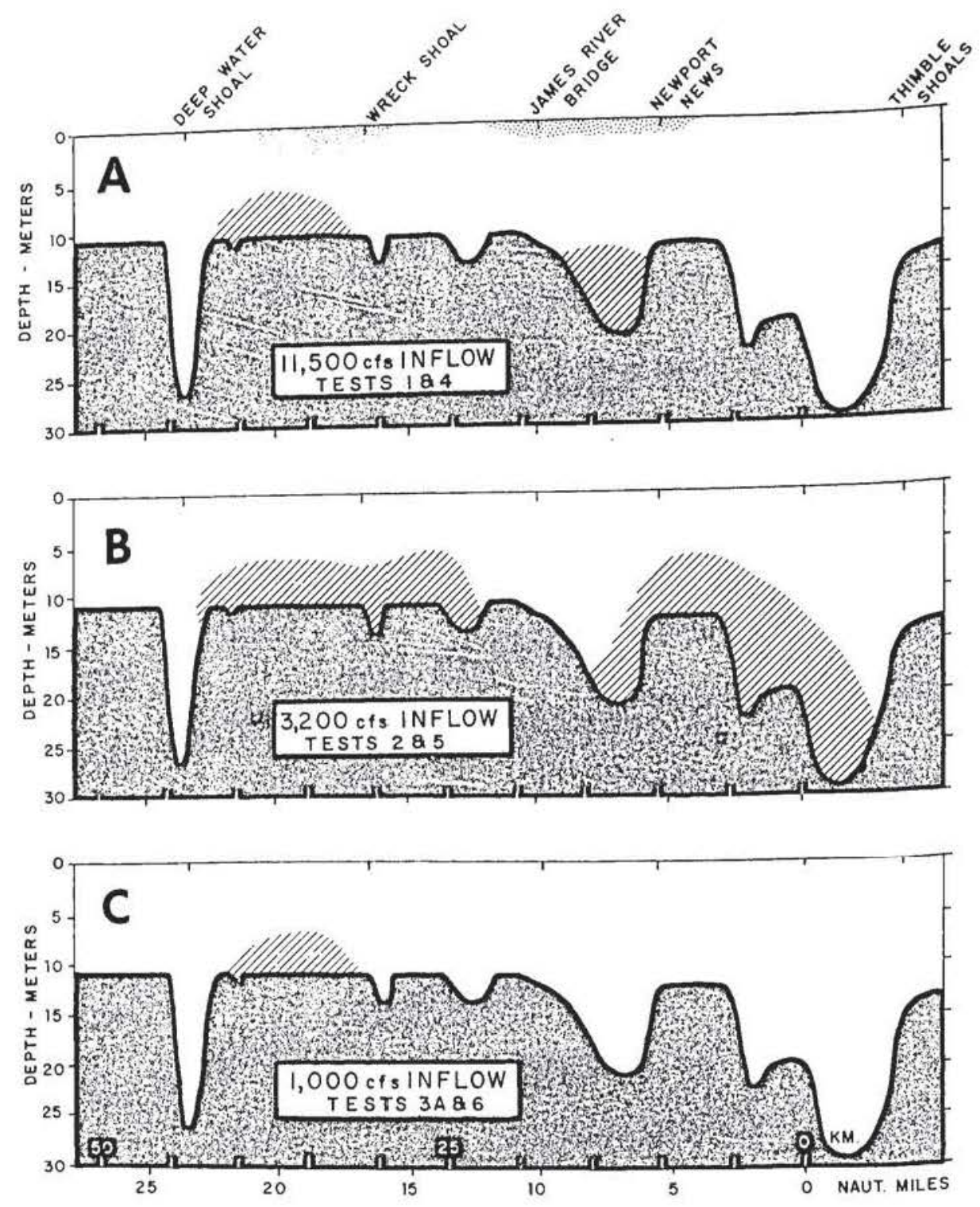

\section{SALINITY CHANGE, \%。}

\section{SALINITY INCREASE Greater than + $0.5 \%$ 。}

\section{SALINITY DECREASE Less than $-0.3 \%$ 。}

Figure 10. Profile of James River estuary and differences of salinity due to deepening the 35 -foot $(10.7 \mathrm{~m})$ channel. Shaded areas represent areas where differences are greater than elsewhere. A. For $322 \mathrm{~m}^{3} / \mathrm{sec}$ steady inflow at Richmond, tests 1 and 4 . B. For 89.6 $\mathrm{m}^{3} / \mathrm{sec}$ steady inflow at Richmond, tests 2 and 5 . C. For $28 \mathrm{~m}^{3} / \mathrm{sec}$ steady inflow at Richmond, tests $3 \mathrm{~A}$ and 6 . Salinity in parts per thousand $(\% \circ)$. 


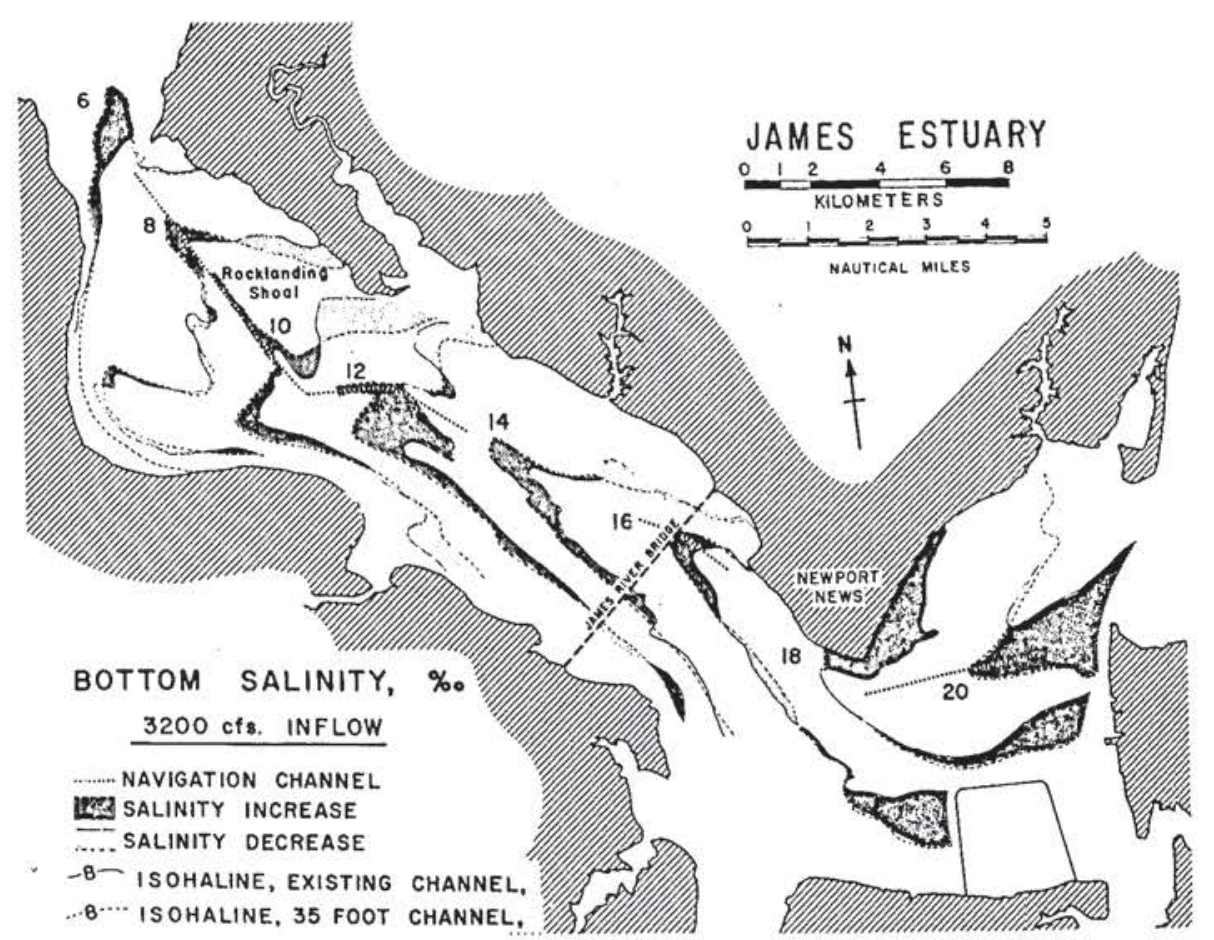

Figure 11. Distribution of bottom isohalines in the model before and after channel deepening, at $89.6 \mathrm{~m}^{3} / \mathrm{sec}$ steady inflow at Richmond. Salinity in parts per thousand $(\% \circ)$.

(Simmons, 1966); others may reflect turbulence or limitations in model operation and measurements. Comparison of time-averaged flow values from test to test, before and after deepening, showed no large differences. Most percentage values of flow predominance (total flow downstream) varied over relatively wide limits so that small changes related to channel deepening were difficult to recognize. When the velocity values were averaged throughout the upper layer and throughout the lower layer, however, there was a trend for a slight reduction of flow in both layers at all conditions of fresh-water inflow.

To examine relatively small changes in the volume rate of flow produced by deepening, salt balance equations of Pritchard (1965) were employed. These equations are based on the assumption that there is a balance between the volume of water entering and leaving any particular cross section. Furthermore, the average salinity of the outflowing water must equal that of the inflowing water. It was found that deepening produced a general reduction in the net transport, both in the upper and lower layers. The greatest reduction of flow, about 20 percent, was found near the head of the Rocklanding Shoal channel in the same area where salinity change was also large.

Trends in the level of no-net-motion, delineated from net velocity measurements, displayed numerous changes in slope both in transverse sections and along the channel course. In a straight reach of the middle estuary near James River bridge, the level often sloped upward toward the channel from both the north and the south shoulders. Therefore, upstream flow chiefly was confined to the 
channel, whereas downstream flow passed seaward mainly over the shoals. The marked rise in the level over the channel suggests a crowding of upstream flowing water as it passes from the relatively deep lower estuary into the shoal middle estuary. Farther upstream, in the Rocklanding Shoal channel, a change from flood to ebb predominance, called a node (Schultz and Tiffany, 1965), was observed near the channel floor. The node was found in the same location in each test at all levels of fresh-water inflow in the salinity zone of 3 to 12 parts per thousand at 35 to 45 kilometers above the mouth. Its persistence in the same area through a range of salinity suggests that its location is due to geometry rather than to density gradients (Simmons, 1966).

Changes in the depth and slope of the level of no-net-motion due to channel deepening were not clearly evident. Differences from test to test probably were masked by the larger variations from place to place. While direct measurement and computation of the level were uncertain, the pattern of salinity change in the middle estuary with freshening of the upper layer over the shoals indirectly suggests that the level was slightly lower after deepening.

Effects of channel deepening on tidal elevations and tidal ranges were limited to upper reaches above Hopewell, and they were very small, less than \pm 0.91 millimeter in the model or \pm 9.1 centimeters in the prototype. Low-water elevations were lowered slightly while high-water elevations were lowered a smaller amount, resulting in a slight increase in tidal range (Simmons, 1966).

\section{DISCUSSION}

It has been recognized that the depth of an estuary is one of the important physical parameters controlling the type of net circulation (Pritchard, 1955). Width, tidal velocity, and river inflow are the other important parameters. When the river inflow parameters are held constant, the effect of increasing the depth is to increase the cross-sectional area of flow, particularly below the level of no-net-motion. Consequently, the same tidal velocities will flush a smaller volume of water through the section. With greater haline stratification, tidal forces are less effective in mixing water between the two estuarine layers. Thus, relatively salty inflow passes upstream more effectively near the bottom, whereas river outflow is more restricted to the near-surface layer. The over-all effect of increasing depth is to shift the estuarine circulation pattern from a type C (Pritchard, 1955) toward a type B (Nichols, this volume, Fig. 8).

\section{Biological Implications}

The economically important oyster is intimately related to the salinity and circulation of an estuary. A change in natural living conditions can lead to a change in survival and growth and, in turn, to a change in commercial yield. Because oysters cannot move after setting, they cannot escape predators or diseases by shifting into more favorable areas. In the James, the survival of oysters depends in large part on the restriction of predators and diseases. Destructive oyster screw-borers or drills are confined to lower reaches of the oyster grounds by occasional floods or freshets that reduce salinity to less than about 10 parts per thousand. Similarly, the disease organism known as MSX (Minchinia nelsoni) is restricted to lower reaches by a salinity of about 10 parts 
per thousand (Hargis, 1966). Therefore, a substantial increase of salinity along the bottom by channel deepening inflow would cause a corresponding upstream intrusion of predators and diseases into the oyster grounds.

Upstream flow and vertical mixing constitute a potentially important mechanism for the transport of oyster larvae. Bousfield (1955) and Pritchard (1952a) have suggested that the larvae, which originate mainly in the lower estuary, are carried headward by net upstream flow in the lower layer. They are further mixed upward and redistributed onto shoals, which are favorable setting grounds. Consequently, substantial reduction in net flow could reduce the number of larvae reaching the oyster grounds in the upper estuary. Since the reduction in net transport, as well as the change of salinity due to channel deepening in the model was so small, no significant change in the natural dispersal of larvae or the upstream distribution of oyster predators and disease is predicted.

\section{Geological Implications}

The model results indicate that the salinity and flow regimes of an estuary are sensitive to small depth changes. A slight change beyond a critical depth or threshold may have a relatively large effect and thus contribute to the pronounced lithologic variations that characterize estuarine deposits. Assuming river inflow, width, and tidal velocities are maintained constant, a decrease in depth by sedimentary infilling would permit tidal forces to be more effective in mixing water between upper and lower layers, and therefore reduce stratification. The salinity distribution would be shifted in the estuary proper to such an extent that the upper layer would become saltier especially on the right side (looking upstream), and the lower layer would become fresher with the most pronounced freshening on the left side. Penetration of the salt intrusion would be reduced near the estuary head. Shoaling would change the estuarine circulation pattern from a type B toward a type C (Pritchard, 1955; Nichols, this volume, Fig. 8). Sediment transport should become faster and redistribution more active as the net flow is increased and as wave agitation becomes more effective on the shoaling floor. A greater portion of the river-borne sediment load would be flushed through the estuary, whereas the smaller entrapped load would be deposited in widely dispersed zones; that is, it would be less concentrated at the head of the salt intrusion or along the intersection of the level of no-net-motion with the bottom. Bottom sediments in the estuary proper should become less pyritic, more calcareous and fossiliferous, and more lagoonal in character. These changes probably are now occurring in the prototype James where sedimentary infilling exceeds the rate of subsidence and sea-level rise by more than 40 centimeters per 100 years. In the real estuary, however, effects of short-term changes, fluctuations of river-inflow, are superimposed on the long-term changes producing marked vertical and lateral variations in deposits. Once the salinity and flow regimes have shifted, the estuary should become more sensitive to changes in river inflow and wave action than to changes in depth.

\section{SUMMARY}

Measurements of salinity and flow made in a hydraulic model at steady-state conditions indicate that a 3 -meter increase in channel depth would produce only 
a small change in the salinity regime and a slight reduction of flow. The significant results are:

1. The salinity change, though small, was most pronounced in the middle estuary where the major channel enlargement was performed.

2. The salinity change was generally greatest and most widespread at conditions of intermediate inflow (89.6 cubic meters per second at Richmond), whereas the change was smallest at very low inflow ( 28 cubic meters per second at Richmond).

3. The lower estuarine layer, mainly in the channel, became fresher. Stratification increased most in the channel at high inflow (322 cubic meters per second at Richmond) when salinity was minimal. With greater stratification, vertical mixing between layers was diminished.

4. There was a general trend for a slight reduction of net current velocity and a reduction of net transport in both the upper and lower layers.

5 . The changes in salinity and flow predicted by the model are not sufficient to cause a significant change in oyster production in the prototype.

\section{ACKNOWLEDGMENTS}

This investigation was supported by funds from the Commonwealth of Virginia to the Virginia Marine Resources Commission and in turn, to the Virginia Institute of Marine Science. Ideas expressed in this paper were shaped in discussions with Henry Simmons, D. W. Pritchard, and William Hargis who guided development of the model from its inception to final testing. The author is grateful to numerous people for assistance with multi-ship observations on the estuary. N. J. Brogdon and W. H. Bobb supervised construction and performed model verification and testing. Thanks are due to E. Ruzecki, R. Moncure, W. MacIntyre and Roger Buck of the Virginia Institute of Marine Science for their cooperation in analyzing test data. Jane Davis and Kay Stubblefield drafted the figures.

\section{REFERENCES CITED}

Bousfield, E. L., 1955, Ecological control of the occurence of barnacles on the Miramichi estuary: Canada Natl. Mus. Bull. no. 137, p. 1-69.

Hargis, W. J., 1966, Operation James River [final report]: Virginia Inst. Marine Sci., Spec. Rept. Appl. Marine Sci. Ocean Eng., no. 7, 50 p.

Pritchard, D. W., 1952a, Distribution of oyster larvae in relation to hydrographic conditions: 5th Ann. Sess. Gulf and Caribbean Fish. Inst., p. 123-132.

1952b, Salinity distribution and circulation in the Chesapeake Bay estuarine system: Jour. Marine Research, v. 11, p. 106-123.

- 1955, Estuarine circulation patterns: Am. Soc. Civil Engineers Proc. 81, Paper 717, p. $1-11$.

- 1965, Dispersion and flushing of pollutants, in Wicker, C. F., ed., Evaluation present state of knowledge of factors affecting tidal hydraulics and related phenomena, Rept. 3, Chap. VIII: Comm. on Tidal Hydraulics, 39 p.

Rochford, D. J., 1951, Studies in Australian estuarine hydrology, I. Introduction and comparative features: Australian Jour. Marine Fresh-Water Research, v. 2, p. 1-116.

Schultz, E. A., and Tiffany, J. B., 1965, Effects of density differences on estuarine hydraulics, in Wicker, C. F., ed., Evaluation of present state of knowledge of factors affecting tidal hydraulics and related phenomena, Rept. 3, Chap. V: Comm. on Tidal Hydraulics, $18 \mathrm{p}$. 
Shidler, J., and MacIntyre, W., 1967, Hydrographic data collection for "Operation James River-1964": Virginia Inst. Marine Sci., Data Rept. no. 5, 455 p.

Simmons, H. B., 1955, Some effects of upland discharge on estuarine hydraulics: Am. Soc. Civil Engineers Proc. 81, Paper 792, 20 p.

1959, Application and limitations of estuary models in pollution analyses: 1st Internat. Conf. on Waste Disposal in the Marine Environment, Univ. Calif., p. 540-546.

1966, Effects of a proposed 35-foot channel to Richmond on currents and salinities over the seed oyster beds in James River: U.S. Army Corps Engineers Waterways Expt. Sta., Summ. Rept., 64 p.

Stroup, E. D., and Lynn, J. R., 1963, Atlas of salinity and temperature distributions in Chesapeake Bay, 1952-1961, and seasonal averages, 1949-1961: Chesapeake Bay Inst. Graphical Summ. Rept. 2, 410 p.

U.S. Congress, 1965, Channel to Newport News, Norfolk Harbor, and Thimble Shoal Channel, Virginia: U. S. 89 th Cong., 1st sess., House Doc. 187, 333 p.

Whaley, H. H., and Hopkins, T. C.. 1952, Atlas of the salinity and temperature distribution of Chesapeake Bay, 1949-1951: Chesapeake Bay Inst. Graphical Summ. Rept. 1, Ref. 52-4 (unpaged).

MANUSCRIPT RECEIVED BY THE SOCIETY APRIL 12, 1971

THIS PAPER IS A CONTRIBUTION OF THE VIRGINIA INSTITUTE OF MARINE SCIENCE, NO. 382 